HegedÜS ATtILA - PAPp LAJOS szerk. 1991. Középkori leveleink 1541-ig. Tankönyvkiadó, Budapest. KlEMm ANTAL 1928. Magyar történeti mondattan. Magyar Tudományos Akadémia, Budapest.

SÁROSI ZSÓFIA 2003. Morfématörténet. In: KISS JENÖ - PUSZTAI FERENC szerk., Magyar nyelvtörténet. Osiris Kiadó, Budapest. 129-172, 352-371.

\title{
Complex past tense constructions and their use in Late Old Hungarian
}

Complex past tenses are characteristic grammatical patterns of the Late Old Hungarian period. Given that they were mainly attested in ecclesiastic documents, it was suspected that the categories corresponding to those of Latin grammar had been set up by translators, under the influence of Latin. The paper tries to find out to what extent, in what functions, and in what regions complex past tense forms were typically used in Late Old Hungarian spoken utterances. On the basis of his study of Late Old Hungarian missiles, the author concludes that the use of complex past tense forms was not merely a regional property of language use; that the number of constructions including the auxiliary volt was significant at the end of the Old Hungarian period, therefore the emergence of this phenomenon cannot be simply relegated to Middle Hungarian; and that the constructions megy vala $\sim$ megy volt 'went' and ment vala $\sim$ ment volt 'had gone' were grammatical synonyms in Late Old Hungarian.

Keywords: Late Old Hungarian, spoken language, missile, complex past tense form, grammatical synonym, eyewitness theory, tense and aspect.

HeGEDÜS ATTILA

Pázmány Péter Katolikus Egyetem

\section{SZÓ- ÉS SZÓLÁSMAGYARÁZATOK}

\section{Megjegyzések az ered szócsaládjának eredeztetéséhez}

HORVÁTH KATALIN abban a tanulmányában, amelyet a Ladányi Mária tiszteletére összeállított emlékkönyvbe (2014) írt, részletesen, behatóan vizsgálta meg az ered, ereszt igék származását, szócsaládjukat, valamint a család tagjainak egymáshoz való viszonyát. Lényegében sikerült igazolnia azt a feltevését, hogy az ered és az ereszt olyan származékok, amelyek arra az ősi ér nomenverbumra vezethetők vissza, amelynek a realizációit a TESz. és az EWUng. összesen négy szócikkre, két-két igeire és főnévire bontva mutatja be az igenévszói jelleg említése nélkül.

HORVÁTH KATALIN elemzését nemcsak érdekesnek és tanulságosnak tartom, hanem nagyjából egyet is értek vele. Véleményem szerint azonban vannak olyan pontjai, amelyek finomításra, kiigazításra szorulnak. Ezekhez szeretnék a következőkben néhány megjegyzést fúzni. - A puszta lapszámok természetesen HoRVÁTH KATALIN 2014-es írására vonatkoznak.

HORVÁTH KATALIN azt állítja a TESz.-ről és az EWUng.-ról, hogy „a szócikkekben az ér fönév és az ered, ereszt igék etimológiai összefüggésének, egyazon eredetének a le-

DOI: 10.18349/MagyarNyelv.2016.1.80 
hetősége sem merül föl” (208). Magukat a szócikkeket tekintve ez valóban így van. Az EWUng. mutatója (1997: 138) viszont jelzi az ér ${ }^{3}$ 'patak' és az ereget közötti kapcsolatot, tehát az ered, ereszt igékkel való összefüggést is, hiszen ezek az ereget szócikkben szereplő alcímszavak. Hozzáteszem, hogy a mutató ennél messzebbre is megy, ugyanis az ereget címszóhoz tartozó utalási szakaszban (lehetséges) összefüggést jelez az 'árad; vízáradás' jelentésü ár $r^{l}$ nomenverbummal. - Mivel annak idején az EWUng. megjelentetésekor nem várhattuk meg a teljes szócikkanyag elkészültét, hanem szakaszosan, füzetenként került sor a publikálásra, a szótárt készítő munkacsoport úgy döntött, hogy az etimológiai utalórendszert (ellentétben a TESz. eljárásával) áthelyezi a teljes szócikk-készlet ismeretében összeállítható mutatóba (vö. HORVÁTH LÁSZLÓ 1995). Az utalások pontosságának, kiterjeszthetőségének, gazdaságosságának kétségtelenül jót tett ez a megoldás, mindmáig érezhetôen megvan azonban az a hátránya, hogy az etimológiai utalások nagy része (a szócikkek szövegében nem szereplök) „elbújik” az olvasók szeme elől. Tapasztalatom szerint sokan nem is tudják, hogy az EWUng. mutatója etimológiai utalórendszert is tartalmaz. - A HORVÁTH KATALINtól idézett részlet is bizonysága annak, hogy az Új magyar etimológiai szótárban (ez GERSTNER KÁROLY vezetésével készül az MTA Nyelvtudományi Intézetében) érdemes az utalásokat áthelyezni (visszahelyezni) maguknak a szócikkeknek a végére.

Az elemzés mind az ered szócsaládját, közelebbről az ér nomenverbum képviselőit illetően, mind pedig általánosabb vonatkozásban foglalkozik a homonimafélék szótári kezelésével. HORVÁTH KATALIN egyetértéssel idézi BÁRCZI GÉZÁnak a szótári homonimák túlszaporítását bíráló cikkét (1958), majd önmaga így ír a kérdésről: „Történeti-etimológiai szótárban csak akkor van létjogosultsága a közös hangalakhoz tartozó jelentések több szócikkbe tördelésének, ha a) a belső nyelvi összefüggések ennek nem mondanak ellent; b) a szétválasztott jelentéseknek bizonyíthatóan más-más felmenői vannak” (213). - A HORVÁTH KATALIN szabta feltételek akkor volnának helyesek, ha nem feledkeznének meg a kérdés másik oldaláról. A gyakorlatban ugyanis nem mindig könnyü eldönteni, hogy vannak-e olyan belső összefüggések, amelyek ellentmondanak a homonimáknak tűnő szavak külön-külön felvételének; bizonyítani pedig nemcsak a külön-külön felmenők meglétét kell, hanem az azonos felmenőét is. Ha bizonytalan vagy vitatott esettel van dolgunk, akkor BÁRCZI is inkább a homonímia mellett döntene (1958: 47). Nemrég, a két seb ügyében magam is ilyen okból javasoltam a két címszó megtartását egyesítésükkel szemben (HORVÁTH LÁSZló 2015). Azt viszont elismerem, hogy az ér esetét tekintve HoRVÁTH KATALINnak a címszóegyesítésre irányuló érvelését el lehet fogadni.

A tanulmány nem mindenütt bánik gondosan az etimológiai minősítésekkel. - Azt írja például, hogy az újabb etimológiai szótárak szerint „a 'patak' jelentésú ér bizonytalan, vitatott eredetü" (HORVÁTH KATALIN 2014: 211). Valójában azonban az említett helyeken a szótárírói véleményt világosan tükrözve csak a „vitatott” eredetminősítés szerepel. Érdemes volna pontosítani azt a részletet is, ahol HORVÁTH KATALIN a „,belső keletkezésü” és „fiktív tövü” minősítéseket szembeállítja: „Ha az elemzés eredményeképpen a fölmerült gondolat igazolódik, vagy legalábbis valószínüsíthető, a két ige [ti. az ered és az ereszt] kikerülhet fiktív tövü igéink közül, azaz belső keletkezésű szavaink újabb elemekkel bővülhetnek" (207, vö. még 214). Értem a szerző szándékát, de mivel BENKÖ LORÁND könyvéből (1984) jól tudjuk, hogy fiktív tövü igék minden fő eredetkategóriában vannak, pontosabbnak gondolom azt a megfogalmazást, hogy ,a két ige kikerülhet a »finnugor 
eredetü fiktív tő + magyar képző« felépítésü igéink közül, azaz egyértelmüen belső keletkezésű származékszónak minősíthetővé válhat".

Az elöző bekezdésben említetteknél nagyobb bajt látok abban a kijelentésben, hogy az ér ige hatalmas szócsaládja ennek az igének az „ősi volta, de egyúttal belső keletkezése mellett is szólhat" (213). - Az igaz, hogy a szócsalád kiterjedtsége összhangban volna a belső keletkezéssel, csakhogy maga az ér tőige, így belső keletkezésü legföljebb akkor lehetne, ha onomatopoetikus volna.

Az említett kifogásoktól függetlenül szeretném kiemelni HORVÁTH KATALIN tanulmányának azt az erényét, hogy nem elégszik meg az egyes, izolált szavak eredetvizsgálatával, hanem az összefüggések feltárására (is) törekszik. Ö ezt különösen a b e 1 s ő nyelvi összefüggésekkel kapcsolatban hangsúlyozza. - Az összefüggések felderítését az elszigetelt szavakra irányuló vizsgálódás kiegészítésére, illetve azzal szemben magam is kiemelt célként kezeltem az etimológiai szótári u ta lóre nds zerrel foglalkozó írásaimban (HORVÁTH LÁSZLÓ 1991, 1995, 1996), valamint az a la p n y e lvbő 1 örö költ szókészlettel kapcsolatban (HORVÁTH LÁSZLÓ 2008).

Végül hadd említsem meg, hogy HoRVÁTH KATALIN tanulmányát a készülő Új magyar etimológiai szótár (= ÚESz.) nemcsak az ered szócsaládjával kapcsolatban hasznosíthatja, hanem mint a szótáron dolgozó kutatócsoportnak a tagját engem is arra ösztönöz az elemzés, hogy vizsgáljam meg az EWUng. ,indexes” címszavait, különösen a jelentéselkülönülés eredményének minősítetteket: hátha csökkenthetjük a számukat.

\section{Hivatkozott irodalom}

BÁRCZI GÉZA 1958. A szótári homonímia kérdéséhez. Magyar Nyelv 54: 43-52.

BENKÖ LORÁND 1984. A magyar fiktív (passziv) tövü igék. Akadémiai Kiadó, Budapest.

EWUng. = Etymologisches Wörterbuch des Ungarischen 1-2. Hrsg. BENKÖ, LORÁND. Akadémiai Kiadó, Budapest, 1993-1995. + Register. Akadémiai Kiadó, Budapest, 1997.

HoRVÁTH KATALIN 2014. Jelentés, szerkezet, etimológia. Az ered, ereszt igéink szócsaládjáról. In: HAVAS FERENC - HorVÁth KATAlin - KUgler NóRA - VladÁr ZsuZSA szerk., Nyelvben a világ. Tanulmányok Ladányi Mária tiszteletére. Segédkönyvek a Nyelvészet Tanulmányozásához 160. Tinta Könyvkiadó, Budapest. 206-215.

HoRVÁTH LÁSzLÓ 1991. A TESz. utalórendszere és a szláv jövevényszavak. In: HAJDÚ MIHÁLY KISS JENÖ szerk., Emlékkönyv Benkö Loránd hetvenedik születésnapjára. ELTE, Budapest. 275-277.

HORVÁTH LÁSZló 1995. Etimológia és utalórendszer. Magyar Nyelv 91: 447-453.

HoRVÁTH LÁSZLÓ 1996. Új úton az etimológiai összefüggések feltárásában és jelzésében. Annales Universitatis Litterarum et Artium Miskolciensis 6: 41-48.

HoRVÁTH LÁSZLÓ 2008. Alapnyelvi örökség és új etimológiai összefüggések. In: BÜKY LÁsZLÓ FORGÁCS TAMÁS - SINKOVICS BALÁZS szerk., A nyelvtörténeti kutatások újabb eredményei V. Szegedi Tudományegyetem Magyar Nyelvészeti Tanszék, Szeged. 81-86.

HoRVÁTH LÁSZló 2015. A két seb ügyében. Magyar Nyelv 111: 458-464. http://dx.doi.org/10.[-] 18349/MagyarNyelv.2015.4.458.

TESz. = A magyar nyelv történeti-etimológiai szótára 1-3. Főszerk. BENKŐ LORÁND. Akadémiai Kiadó, Budapest, 1967-1976.

HORVÁTH LÁSZLÓ

MTA Nyelvtudományi Intézet 